\title{
CHANGES IN FUNCTIONING OF THE EMERGENCY NOTIFICATION SYSTEM AND THE 112 EMERGENCY NUMBER IN POLAND
}

Introduction. Striving to improve performance should be a characteristic feature of any system. This particularly concerns systems dedicated to the protection of human life and health. The efficiency of these systems often decides about the survival of an injured person. Such a system is the emergency notification system, which has been functioning in Poland since 2013, responsible for the efficient operation of the emergency number 112.

Results and discussion. The article presents the organization of the emergency notification system, which operates throughout Poland in a continuous system. Emergency numbers are handled by Rescue Notification Centres, which operate in 16 voivodships and additionally in the capital city of the country - Warsaw. Since the launch of the emergency notification system, several changes have been introduced, aimed at improving its efficiency and enhancing the functionality of the 112 emergency number.

It has been assumed that the emergency notification system consists of the emergency notification centres (CPR), constituting a uniform system for handling emergency calls directed to the emergency number 112. Handing over such a call enables the initiation of the rescue procedure and involvement of relevant rescue resources. Specific rescue tasks in the system are performed by medical rescue units, fire brigades and police. Many other services also cooperate with the system, such as gas and electricity emergency services.

Conclusions. As a result of the study, it was concluded that changes in the emergency notification system contributed to increasing its efficiency. Integration of the fire brigade (998) and police (997) emergency numbers under a common 112 number enables a quick rescue action and dispatching the appropriate formation. The change of positions in Rescue Notification Centres should also be assessed positively. Emergency number operators can be promoted and improve their qualifications. It has been acknowledged that non-alarm notifications, which block the system and increase the financial costs of its operation, are still a problem in the functioning of the emergency notification system. Therefore, continuous education of the public should be carried out in order to raise awareness of the principles of use of the emergency number 112 .

Key words: emergency notification system, emergency numbers, integration of rescue operations, emergency number operator.

Олександра Шкрабач, Поморська Академія в Слупську, Польща

\section{ЗМІНИ У ФУНКЦІОНУВАННІ СИСТЕМИ ОПОВІЩЕННЯ ПРО НАДЗВИЧАЙНІ СИТУАЦІї ТА ЗА НОМЕРОМ ВИКЛИКУ 112 У ПОЛЬЩІ}

Вступ. Прагнення до підвищення продуктивності має бути відмінною рисою будь-якої системи. Особливо це стосується систем, призначених для захисту життя та здоров'я людей. Ефективність цих систем часто визначає виживання пораненої людини. Такою системою є система оповіщення про надзвичайні ситуації, яка діє в Польщі з 2013 року і відповідає за ефективну роботу екстреного номера 112.

Результати і обговорення. У статті представлено організацію системи оповіщення про надзвичайні ситуації, яка діє на всій території Польщі в безперервній системі. Екстрені номери обслуговуються Центрами екстрених сповіщень, які діють у 16 воєводствах та крім того у столиці країни - Варшаві. 3 моменту запуску системи екстреного оповіщення було внесено ряд змін для іï покращення та розширення функціональності екстреного номера 112. Передбачалося, що система екстреного оповіщення складається з центрів екстреного оповіщення (ЦПР), які утворюють єдину систему обробки екстрених повідомлень, що надсилаються на номер екстреної служби 112. Передача такого повідомлення дає змогу розпочати екстрену процедуру та залучити відповідні екстрені ресурси. У системі спеціальні рятувальні завдання виконують медичні рятувальні підрозділи, пожежні підрозділи та поліція. Багато інших служб також співпрацюють із системою, наприклад, аварійні служби газу, служби аварійної енергетики. 
Висновки. У результаті дослідження було виявлено, що зміни в системі оповіщення про надзвичайні ситуації сприяли підвищенню їі ефективності. Об’єднання номерів екстрених служб пожежної команди (998) та поліції (997) під загальним номером 112 дозволяє швидко провести рятувальні дії та забезпечити наявність правильного формування. Позитивно слід оцінити і зміну роботи в Центрах оповіщення про надзвичайні ситуації. Операторів екстрених служб можна підвищити та підвищити їхню кваліфікацію. Виявлено, що нетривожні сповіщення, які блокують систему та збільшують фінансові витрати на її роботу, залишаються проблемою в роботі системи екстреного сповіщення. Тому необхідно проводити безперервні навчання суспільства 3 метою підвищення рівня знань про правила користування екстреним номером 112.

Ключові слова: система оповіщення про надзвичайні ситуації, номери екстрених служб, інтеграція рятувальних заходів, оператор екстреного номера.

Introduction. Providing security to citizens is a constitutional duty of the Polish state, which is fulfilled by establishing and maintaining adequate forces and resources to protect and defend the population against threats of the 21 st century, resulting from both natural forces and human activity.

In everyday situations, in order to react to accidents threatening the health and life of people, including such incidents as road, rail, electrical or water supply network failures, there have been appointed fulltime, specialized units whose task is to provide quick, professional and necessary assistance. These include first and foremost the medical rescue units, fire brigade and police, as well as all kinds of municipal services such as electricity and gas services.

The basic link in rescue actions, which initiates undertaking a rescue action, is information about a threat or an event, which generates subsequent stages of proceedings. Therefore, it has become necessary to introduce a uniform system of rescue notification, the purpose of which is to receive the notification about danger, its qualification and dispatching appropriate rescue forces and resources. The organisation of such a system was based on the Act of 22 November 2013 on the emergency notification system, which has been amended several times since its enactment. The main objective of the article is to present legal, organisational and functional changes in the emergency notification system in Poland and their assessment in terms of increasing the quality of functioning of this system. The article seeks to answer the main research problem in the form of a question: what changes have been introduced in the emergency notification system in Poland and how they have affected the quality and effectiveness of its functioning. While conducting research within the framework of this article, first of all, theoretical methods were used, including analogy, which was useful while adjudicating on certain features of the system, defining, which allowed to determine the unambiguity of concepts within the scope of the object under study, analysis and synthesis in the area of literature on the subject, systemic analysis, which allows to present functions and elements of rescue service in a systemic way, induction and deduction, thanks to which logical interpretation and drawing conclusions based on the analysis of source data was possible.
The research resulted in the following conclusions: firstly, that after eight years of operation of the emergency notification system, it was necessary to introduce changes in it resulting from social practice, secondly, that changes in the emergency notification system contributed to the improvement of its functioning, especially in the area of integration of emergency numbers, and improvement of competence and motivation of professional emergency number operators.

Research methods. The following research methods have been used: analysis and synthesis of the literature on the subject, allowing for systematization of issues related to the subject of research; system analysis, allowing for presentation of functions and elements of rescue service viewed systemically; induction and deduction, allowing for logical interpretation and drawing conclusions, based on analysis of source data.

Results and discussion. In Poland the need to create the system arose from the necessity to integrate the tasks of dispatchers of health care units with the State Fire Service units and the Police units. This idea was connected with the requirement to increase the quality of organized rescue actions and also with the increase of effectiveness of passing information

The idea was connected with the requirement to increase the quality of organised rescue actions and also to increase the effectiveness of passing information on the threat. This requirement was imposed on Poland by Directive 2009/136/EC of the European Parliament and of the European Council of 25 November 2009 amending Directive 2002/22/EC on universal service and users' rights relating to electronic communications networks and services .

The Emergency Notification System Act adopted in 2013 became the basis for the functioning of the system based on the operator model, where the operator handles all notifications, passing them on to dispatchers. The emergency number is handled by Rescue Notification Centres located in sixteen voivodeship cities, and additionally in Radom. They took over the service of notifications from two basic rescue services, i.e. National Fire Service and Police. Their task was to receive emergency calls and forward them to an appropriate dispatcher. The aim was to accelerate rescue actions and to relieve the dispatcher from handling non-emergency notifications (related to life, 
health, property or environmental threats), and thus not not notifications requiring the intervention of services.

The system was defined as a unified national system for the receipt of calls to 112, consisting of a network of Rescue Notification Centres (CPR), whose purpose is to receive, process and handle calls, in particular to transmit detailed information on the incident to the territorially competent control points of services statutorily established to provide assistance .

The Rescue Notification Centre is defined as: "a point for receiving notifications directed to the emergency number 112. CPRs function in voivodship offices, within the organisational unit responsible for crisis management. CPRs accept notifications from the emergency number 112 and redirect notifications to the relevant unit of the Police, State Fire Service and ambulance service [...] ensuring current cooperation with the units of the system" . The CPR tasks include :

-handling alarm calls, excluding fire alarm systems equipped with signalling and alarm devices, including:

-receipt of alarm notification,

-Linking an emergency call with the contact details of the place of call and its geographical position, selection of appropriate group of entities, to which collected data on emergency call will be directed, exchange of data on emergency notifications processed in teleinformatic system with Police, PSP, medical rescue teams dispatchers or other entities, whose telephone numbers are handled within the system.

CPRs cooperate with the pan-European rapid notification system for road accidents eCall, which is related to the "esafety" initiative, which is part of the EC's comprehensive strategy to maintain road safety and improve transport efficiency in the EU. Once activated, the eCall in-vehicle device will connect via the mobile phone network to the emergency services, allowing the transmission of electronic data and establishing a voice connection. Notifications are handled by the Emergency Notification Centres (ERC), part of the 112 emergency phone network.

Apart from the emergency number 112, the Rescue Notification Centres also handle other numbers these are mainly 997 (Police), 998 (Fire Brigade), 999 (Medical Rescue), as well as other national emergency numbers, including: 991 (energy emergency), 992 (gas emergency), 993 (district heating emergency), 994 (water and sewage emergency) and 987 (coordination and information number for the government administration in the voivodship for crisis management purposes), as well as others whose tasks include the protection of life, health, safety and public order, property or the environment.
In accordance with the adopted model for handling notifications, an indirect operator system operates in Poland. As mentioned earlier, the reporting party makes a call to the emergency number (112, 997, 998, 999). He/she hears an announcement on the phone lasting 5 seconds: "Emergency number 112, please wait for the operator to answer". (in 2016 the announcement was shortened from 6 to 5 seconds). The operator takes the call by pressing the "Answer" button on the operator console. If he does not answer the phone within 10 seconds, the call goes to the next available operator from the centre. However, if no operator from the centre picks up the call within $45 \mathrm{sec}$ onds, it will go to the first least busy operator in Poland - without taking into account the principle of mutual substitutability. Additionally, an operator who is free and does not answer the phone will be penally logged out of the console.

After taking a call, the call handling process follows. This process is a set of actions whose goals are: receiving a notification, qualification, forwarding to the appropriate service or other entity (whose number is handled within the system), as well as monitoring the status of this notification . Reception is the initiation of call handling by selecting the "Answer" button on the console and the operator's introduction. Qualification means making a decision by the operator whether a report qualifies as an emergency report, i.e. whether it has the features of urgency and danger. Transmission of the report is made by sending a document about the event to the appropriate entity or by transferring the information by phone. Monitoring is a check of the status of the notification starting from the command: "delivered to SWD" and ending with "completed" .

Each of the notifications should have a unique identifier, the number from which the call was made, date and time of acceptance of the notification, identifier of the emergency number operator who handled the notification, type of event (voice, SMS or SWD), information on the location of the network termination point, subscriber's data (if recorded). Additionally, emergency notifications should also contain information on location of the event or threat, description of the event or threat, information on the injured, information on the reporting person.

The general scheme for handling requests is based on the principle of three questions: Where, What, Who. In principle, the place of the event is the most important information for the operator. Additionally, the operator should handle the call as quickly as possible. The average time for handling emergency events in 2015 was 69 seconds and in 2017 it was about 128 seconds. The real problem of the functioning of the emergency notification system has become the so-called non-alarm notifications. Annual statis- 
tics show that the operator of emergency numbers receives non-emergency calls in $80 \%$; which, translating into daily statistics, means that during this shift the operator handles an average of 150 calls, of which 124 are non-emergency calls. On a national scale, out of about 19 million calls, only 4 million are emergency calls. The rest are, to a large extent, unfounded, malicious or deaf calls, or calls generated by the telecommunications network itself, by unblocked telephones or by children playing with the phone.

The Emergency Notification System Act adopted in 2013 provided the basis for the organisation of the system, the main task of which is to initiate a rescue action as soon as possible and to shorten as much as possible the notification path between the injured person and the rescuer. Since the enactment of the Act 8 years have passed, which have verified the effectiveness of the introduced solutions and the efficiency of operations carried out within the system. Therefore, on the basis of the collected experience, it is worthwhile to present changes in the functioning of the aforementioned system, which are aimed at improving the quality of emergency numbers in Poland.

The amendment of the Act of 17 September 2020 amending the Act on the emergency notification system primarily concerned the gradation of positions occupied by persons handling emergency numbers into: emergency number operators, senior emergency number operators, coordinators and coordinatortrainers. Hierarchisation of positions in emergency call centres allowed, above all, for promotion of employees with longer work experience, improvement of competences in order to take up a higher position, and thus the possibility to earn higher salaries. The amendment to the Act also specified the requirements to be met by candidates for the positions of operator, senior operator, coordinator and coordinator-trainer of emergency numbers.

Moreover, persons holding the above-mentioned positions, while performing their duties, have been subject to legal protection provided for in the Act of 6 June 1997. - Penal Code for public servants. This means that the operator of an emergency number is protected by law against verbal abuse or threats, which is a frequent case in the work of a dispatcher, especially when on the other side of the handset there is a person in an intoxicated state.

Apart from functional changes, in the emergency notification system in the office serving the minister in charge of public administration, the National Monitoring Centre for the Emergency Notification System has been established, whose tasks include maintaining continuity of operation of the ICT system; preparing and carrying out basic and in-service training for operators of emergency numbers, senior operators of emergency numbers, coordinators and coordinators-trainers, managers of rescue notification centres and their deputies; supervision over observance of procedures for handling emergency calls, in particular by preparing a quarterly card for assessment of the centre's work; and international cooperation with regard to operation of the system, as well as dissemination of knowledge on the principles of using emergency numbers.

The idea of functioning of the emergency notification system assumes integration of many rescue entities within the 112 emergency number, which also includes PKP Państwowe Linie Kolejowe S.A. This company has taken the initiative to additionally mark every level crossing under its management since 1 January 2018. The \#YellowStickerPLK project consists in additional marking with an individual identification number of each railway-road crossing.

The information, in the form of yellow stickers, can be found on level crossings on the inside of $\mathrm{St}$ Andrew's crosses or by the posts to which the horn arm is attached. Each sticker has three important numbers. The first is the individual number of the level crossing. The second is the emergency number 112 , which must be dialled in the event of a lifethreatening emergency. The operator of the 112 emergency number, after entering the crossing number, can determine precisely where help should be sent. $\mathrm{He}$ or she also has the ability to quickly connect with railwaymen who can stop train traffic on the line. The third number is an emergency number for reporting non-life-threatening faults.

In many cases, the yellow sticker has saved lives. If a car breaks down on the crossing or the tracks are blocked, the information on the sticker can prevent a tragedy. One did not have to wait long for the effects of this action. In the first year alone since the introduction of the Yellow Sticker, at the end of 2018. 165 times train traffic was stopped or restricted after a phone call giving the number of a crossing where there was a threat to life, the possibility of tragedy, loss and traffic problems .

Another innovation introduced as part of the emergency notification system is the mobile application Alarm 112 launched by the Ministry of the Interior to send emergency calls to the CPR. The application enables, in the situation of threat to life, health, property, environment, security and public order, sending emergency notification to CPR by persons who cannot make a voice call, in particular deaf and hard of hearing persons.

In the application, by selecting appropriate pictograms, it is possible to specify the type and place of the incident and indicate the service whose assistance is necessary. Information provided in this way enables the operator of emergency numbers to forward the event to appropriate emergency services depending on the type and place of the event. 
As part of the improvements to the emergency notification system, in 2017-2018 the emergency number 997 was switched to the Rescue Notification Centre nationwide. As a result, all notifications directed to the emergency number 997 in Poland are now handled by the centres in the same way as notifications to the emergency number 112. This solution allowed for streamlining and accelerating the handling of legitimate emergency notifications.

Until November 2021, the process of switching to CPR - on the same basis as for the 997 number the 998 emergency number handled by the State Fire Service is underway. According to the assumptions of this process, in February this year a pilot switchover of this emergency number was carried out in two voivodships: Podlaskie and Lubelskie. As a result, all notifications directed to the emergency number 998 from the area of Podlaskie voivodship are currently handled by the Rescue Notification Centre in Białystok, just as all notifications to the emergency number 112. Whereas the CPR in Lublin handles calls to the number 998 from the area of Lubelskie voivodship. Currently, the process of switching from 998 to 112 is underway in the Mazowieckie Voivodship, and the last to undergo the process of change will be the Zachodniopomorskie Voivodship. In accordance with the provisions of the Emergency Notification System Act, the 999 emergency number, currently handled by medical dispatch centres, is also to be switched over by 31 December 2023.

The benefits that will be visible after completion of the process of integration of all the existing emergency numbers - the so-called nine numbers under 112 - will consist in simultaneous and automatic - through an ICT system - notification by the emergency number operator of all services appropriate for the type of incident. Moreover, such organisation will relieve police and fire brigade on-duty officers in accepting all calls, both legitimate and unfounded ones. In the integrated model, 112 operators will select notifications and forward - usually only in electronic form - only those requiring intervention. This will be of particular importance at the time of crowded emergency calls, which so far happened to both police officers and firefighters e.g. during weather phenomena or other.

Another effect of switching the emergency numbers 998 and 999 to the emergency notification centres is to unify the way of handling calls directed to emergency numbers, including foreign language calls.

The time of the covid-19 pandemic is particularly difficult for the functioning of emergency services. People, fearing for their lives and health, seek information and assistance in emergency situations using emergency numbers above all. And although, for the duration of the pandemic, the public administration has set up at least several hotlines dedicated solely to providing information about the virus, its symptoms and the course of treatment, emergency call centres have also felt the burden of the increased number of emergency calls.

In 2019, CPRs in the country received a total of 22274931 emergency calls, of which as many as 8605313 (39\% of the total) were false, malicious or unfounded . It is worth adding that the percentage of unfounded calls decreased by more than $3 \%$.

To the emergency and auxiliary services, information on 6198400 events was transferred from the CPR, of which 3550269 alarm events were transferred to the Police, 262816 to the State Fire Service, 2425201 to the PRM medical dispatchers, and 481 112 to other services.

In 2020, the emergency notification system recorded a total of 21391864 incoming calls . Of which, as many as $8182982(38.25 \%)$ were unjustified calls, and the number of cancelled calls was almost $28 \%$. The number of legitimate calls accounted for $7,285,782(34.06 \%)$. Out of the total number of calls, 3485922 were transferred to the Police, 2701 413 to PRM, 262464 to PSP, 591594 to other services. The average waiting time for acceptance of a notification from the 112 emergency number operator is about 9.8 seconds.

The system during a pandemic functions without changes. It handles as standard the receipt of notifications concerning threats to human life and health. A pandemic is just such a case, only on a larger scale. The rigours of a pandemic do not affect the way CPR works. On the other hand, the pandemic condition influenced the increase in the number of accepted notifications.

With each call, CPR staff ask whether the patient is symptom-free and in quarantine. If a patient reports symptoms of illness, suspected coronavirus infection or is in quarantine, CPR informs services directed to the place of intervention, i.e. ambulance, police, fire brigade. The idea is for officers to be able to protect themselves during the intervention. Among emergency calls related to Covid-19, most concerned:

- ill health of the caller;

- symptoms of virus infection;

- quarantine and breaking it;

- contact with sanitation services;

- inappropriate behaviour in public spaces.

However, emergency call operators also accepted non-emergency calls concerning a person coughing in a tram or a salesman with a runny nose.

Conclusions. Based on the research conducted, it can be concluded that:

- firstly, the emergency notification system is a complex organisation that is constantly evolving, among other things, through new experiences resulting from social practice. Therefore, it requires perma- 
nent and holistic research, which will contribute to increasing the quality of conducted activities and will be a response to the social demand in the area of improving rescue procedures;

- secondly, continuous civilization development gives a chance to use modern technologies in rescue notification system, which contributes to increasing the effectiveness of its operation;

- thirdly, the multiplicity of rescue entities, the division of competences and responsibilities causes the need for integration and coordination of rescue activities, which is facilitated by the consolidation of emergency numbers under the pan-European emergency number 112;

- fourthly, the use of ever newer rescue techniques and technologies, including mobile telephony, GPS locators, mapping of dangerous places and the possibility to initiate rescue operations using emergency numbers requires careful personal, technical and organisational preparation, but above all awareness-raising in society, so that these tools do not become 'toys' in the hands of irresponsible people.

\section{Список літератури:}

1. Директива 2009/136 / ЕС Свропейського Парламенту та Ради від 25 листопада 2009 року про внесення змін до Директиви 2002/22 / ЕС про універсальну послугу та права користувачів, що стосуються мереж та послуг електронного зв'язку, Журнал оф UE 2009, L337 / 11.

2.https://www.bezpieczny-przejazd.pl/ aktualnosci/detail/11022021-r-europejski-dziennumeru-alarmowego-112/, звернення 10.02.2021, [в:] G. Nowacki, А Шкрабач, К. Больц, Функціонування системи екстреного сповіщення під час загрози епідемії через Covid-19, доповідь, представлена під час наукової конференції «Логістика у порятунку», організованої Технологічно-гуманітарним університетом у Радомі 9 вересня. 2021 рік.

3. Конституція Республіки Польща від 2 квітня 1997 року «Республіка Польща охороняє незалежність і недоторканність своєї території, забезпечує свободи і права людини і громадянина, безпеку громадян, охороняє національну спадщину та охороняє навколишнє середовище. , керуючись принципом сталого розвитку».

4. Міністерство адміністрації та цифровізаціï, Звіт про функціонування SPR у 2015 році, Варшава 2015.

5. Міністерство внутрішніх справ та адміністраціï, System Concept 112, Варшава 2007.

6. Міністерство внутрішніх справ та адміністрації, Інструкції щодо обробки повідомлень у моделі ІКТ, Варшава 2016.

7. Новацький Г., Скрабач А., Больц К., Функціонування системи екстреного сповіщення під час загрози епідемії через Covid-19, доповідь під час наукової конференції «Логістика у порятунку», організованої Технологічно-гуманітарним університетом у м. Радом 9.09.2021

8. Номер 112 за 2019 рік, https://www.gov.pl/ web/numer-alarmowy-112/aktualnosc-1, звернення 14.10.2020.

9. Розпорядження Міністра адміністрування та оцифровки від 28 квітня 2014 р. про організацію та функціонування центрів екстреного сповіщення, Журн. Законів 2014 р., ст 574.

10. Скрабач А., Домасевич М., Номер екстреної допомоги 112. Організація та функціонування системи оповіщення про надзвичайні ситуації в регіонально інтегрованій системі порятунку, Варшава 2019.

11. Закон від 22 листопада 2013 р. про систему оповіщення про надзвичайні ситуації, Законодавчий журнал 2013 р., No. 2013 р., ст 1635 рік.

12. Закон від 6 червня 1997 р. - Кримінальний кодекс, журн Законів 2020 р., ст 1444 і 1517 pp.

13. Унікальна місія СЛР. Понад 21 мільйон зафіксованих підключень у 2020 році, https://www.infosecurity24.pl/wyjatkowa-misja-cprponad-21-mln-odnotowani-polaczen-w-2020-roku, доступ 11.10.2021.

\section{References:}

1. Directive 2009/136/EC of the European Parliament and of the Council of 25 November 2009 amending Directive 2002/22/EC on universal service and users' rights relating to electronic communications networks and services, Official Journal of the European Union 2009, L337/11.

2. https://www.bezpieczny-przejazd.pl/aktualnosci/ detail/11022021-r-europejski-dzien-numerualarmowego-112/, accessed 10.02.2021, [in:] G. Nowacki, A. Skrabacz, K. Boltz, Operation of the emergency notification system during an epidemic emergency due to Covid -19, paper delivered during the scientific conference "Logistyka w ratownictwie", organized by the University of Technology and $\mathrm{Hu}-$ manities in Radom 9.09.2021 r.

3 Constitution of the Republic of Poland of 2 April 1997. "The Republic of Poland shall safeguard the independence and inviolability of its territory, ensure human and civil liberties and rights and the security of its citizens, safeguard the national heritage and ensure environmental protection, guided by the principle of sustainable development".

4 Ministry of Administration and Digitalization, Report on the functioning of the SPR in 2015, Warsaw 2015.

5 Ministry of the Interior and Administration, 112 system concept, Warsaw 2007.

6. Ministry of the Interior and Administration, Guidelines for handling notification in the teleinformatics model, Warsaw 2016. 
7. G. Nowacki, A. Skrabacz, K. Boltz, Operation of the emergency notification system during an epidemic emergency due to Covid -19, paper delivered during the scientific conference "Logistyka $w$ ratownictwie", organised by the University of Technology and Humanities in Radom 9.09.2021 r.

8. 112 in 2019, https://www.gov.pl/ web/numeralarmowy-112/aktualnosc-1, accessed 14.10.2020.

9. Regulation of the Minister of Administration and Digitisation of 28 April 2014 on the organisation and operation of emergency notification centres, Journal of Laws 2014, item 574.

10. Skrabacz A., Domasiewicz M., Alarm number 112. organisation and functioning of the emergency notification system in the regionally integrated rescue system, Warsaw 2019.

11. the Act of 22 November 2013 on the emergency notification system, Dz.U. 2013, item 1635.

12. the Act of 6 June 1997. - Penal Code, Journal of Laws 2020, item 1444 and 1517.

13. the Unique mission of CPR. Over 21 million recorded calls in 2020, https://www.infosecurity24.pl/wyjatkowa-misja-cpr-ponad-21-mln-odnotowanych-polaczen-w-2020-roku, accessed 11.10.2021.

\section{* Оглядова стаття}

Стаття надійшла до редакції 02.12.2021. 